\title{
DIE BOODSKAP VAN LUTHER SE 95 STELLINGS*)
}

Verus thesaurus ecclesiae est sacrosanctum evangelium gloriae et gratiae Dei.

Inleiding.

Vandag, 488 jaar gelede, het die duitse monnik, Martin Luther, 'n uitnodiging aan sy tydgenote gerig om 'n geleerde gesprek te voer oor 'n saak wat hom baie naby aan die hart gelê het. Dit was bepaal dat op 1 November 1517 'n groot aflaatfees gehou sou word in Wittenberg, die stad in Sakse waar Luther as 'n professor in die teologie gewoon en gewerk het ${ }^{1}$ ). Omdat Luther ernstige besware teen die aflaatpraktyk van die middeleeuse kerk gehad het, het hy op 31 Oktober 1517 vyf-en-negentig stellings teen die aflaatpraktyk aan die deur van die slotkerk in Wittenberg vasgespyker om só, op 'n manier wat destyds gebruiklik was, 'n akademiese gespreek oor die aflaathandel uit te lok. Terselfdertyd het hy die aartsbiskop van Mainz, in wie se kerkprovinsie die aflaathandel plaasgevind het, verwittig van sy besware teen die aflaatpraktyk ${ }^{2}$ ).

Merkwaardig genoeg het niemand vir hierdie gesprek opgedaag nie, maar die vyf-en-negentig stellings het soos 'n veldbrand deur Duitsland getrek en so 'n enorme belangstelling gaande gemaak dat niemand dit meer oor die hoof kon sien nie ${ }^{3}$ ). Die rede was nie alleen dat die vyf-en-negentig stellings die aflaathandel assodanig 'n gevoelige knou gegee het nie, maar dit was van die begin af duidelik dat die vyf-en-negentig stellings één van die steunpilare van die middelceuse geloof omver gewerp het.

Meer as 'n dekade later het Luther sélf kommentaar gelewer oor hierdie gebeurtenis wat tereg beskou word as die beginpunt van die sestiende ecuse kerkhervorming en gestel ${ }^{4}$ ):

„God het my eintlik onvoorbereid in die arbeid terwille van die Evangelie gestoot. As ek vooruit kon gesien het na wat nou agter my lê, sou ek my nie daarin laat dryf het nie. Maar Gods wysheid is groter as dié van die mens. God het my oogklappc aangesit soos 'n mens vir 'n perd oogklappe aansit wanneer mens op die pad wil ry. Daarom, toe ek destyds begin het, het

*) Rede gehou op 31 Oktober 1965 vir die Gesamentlike Hervormingskommissie van die drie Afrikaanse kerke te Potchefstroom.

1) H. Boehmer, Der Junge Luther, Leipzig 1955, S. 156.

2) Vgl. W. Köhler, Dokumente zum Ablasstreit, Tübingen 1934, S. 143.

3) H. Fausel, D. Martin Luther, Stuttgart 1955, S. 84. Die 95 Stellings is in Nürnberg in Duits vertaal, gedruk en versprei en vandaar het dit in ongeveer 14 dae dwarsdeur Duitsland gesprei. Oral is dit in die openbaar aangeplak en druk bespreek.

4) TR 1, 1206 
ek onse Here God in my kamertjie met groot erns èn van ganser harte gevra dat $\mathrm{Hy}$ alles terwille van Hom sal doen en my daarvan sal weerhou dat ek nié myself, dit wil sê : my wysheid, daar. by sal bring nie. Hierdie gebed het $\mathrm{Hy}$ op 'n grootse wyse verhoor. Mag $\mathrm{Hy}^{\prime}$ ons ook verder genade gee".

\section{Die Situasie waarin Luther opgetree het.}

Om die vyf-en-negentig stellings en die rede waarom dit soveel opspraak verwek het, te kan verstaan, moet 'n oomblik gelet word op die godsdienstig-teologiese klimaat waarin Luther opgetree het.

Dic middeleeuse roomse sakrament van die boete het an die boetvaardige sondaar, nadat hy sy sondes gebieg het, absolusie verleen dit wil sê die toesegging van die vergiffenis van die sonde deur God, die Here. Op grond hiervan kon die gelowige aanvaar dat die ewige straf in die hel hom, op grond van die absolusie, vergewe is. Maar juis hier het in belangrike aksentsverskuiwing plaasgevind. Hoewel die gelowige se sondeskuld voor God deur die sakrament van die boete afgelos word, is die straf wat die kerk op die gedane sonde gelê het nié daarmee opgehef nie ${ }^{5}$ ). Die tydelike, kerklike straf wat op die sondige daad moes volg, moes nou nog gedra word en hierdie straf kon alléén deur boetedoening van die kant van die sondaar afbetaal word. Die botedoening wat deur die biegvader aan die sondaar opgelê is, was aanvanklik besonder swaar : langdurige vastetye, die skenk van groot bedrae geld as aalmoes of bedevaarte wat soms jare kon duur was niks ongewoons nie. Daarby het die kerk geleer dat as die boetedoening van die sondaar hier op aarde nie voldoende was nie, dan sou hy, nà sy dood, netsolank in die vagevuur brand totdat hy die volle gewig van die kerklike straf gedra het. Dit was dan ook geen wonder nie dat die middeleeuse, roomse lidmaat 'n heilige ontsag vir die kerklike straf gehad het nie.

Juis hierin het die aksentverskuiwing gelê dat Gods gebod en sy belofte op die agtergrond van die godsdienstige lewe geskuif is en in die plek daarvan het al die nadruk op die kerk se wil en eise, op menslike reëlings dus, geval. En nadat hierdie éérste verkeerde stap gemaak is, is op hierdie weg voortgegaan.

Om nou die korrektheid en noodsaaklikheid van hierdie opvat. ting te bevestig, is die kerklike strafpraktyk baie streng deurgevoer. Aan die ander kant was dit egter ook nodig om sodanige maatreëls te tref dat dit vir die lidmaat nog moontlik was om die kerklike straf te dra. Vanuit hierdie gedagte ontwikkel dan die roomse aflaatstelsel soos 'n kankergeswel in die vroomheid van die middeleeuse kerk. Die

5) Vgl. o.a. I. Klug, Het Kathođieke Geloof, Heemstede 1939, blz. 343. 
in godsdienstige motief wat die aflaatstelsel moontlik maak, is die kerklike leer van die vagevuur, 'n voorstelling dat daar 'n reinigende vuur is waarin die gelowige, na sy dood, beland om daar eers skoongebrand te word van alle onvoltooide kerklike boetedoening voordat hy na die hemel kan gaan. Die ander motief is die leer van die boetedoening vir die kerklike strawwe wat die gevolg is van die daad. sonde van die mens.

Die aflaatpraktyk begin sy loop in die elfde eeu wanneer die kerk die moontlikheid skep dat in plaas van die moertevolle boetedoening vir die kerklike straf die gelowige deur die middel van 'n optrede wat dic kerk ten gcede kom, dié boetedoening kan verminder. Dit wil sê 'n aflaat of ' $n$ vermindering van die kerklike straf kan verkry. So word in 1063 'n algemene aflaat van alle boetedoening vir kerklike strawwe aan almal gegee wat deelneem aan die kruistog teen die Isalm terwyl die gebruik dan ook algemeen word dat deelname aan die bou van kerke byvoorbeeld, 'n gedeeltelike kwytskelding van kerklike strawwe tot gevolg kan hê. Só word 'n hele nuwe moontlikheid vir die gelowige oopgestel. Die ewige straf in die hel word deur die boetesakrament en die absolusie van die priester van die gelowige weggeneem en deur die vereenvoudigde, maklike boetedoening word dit moontlik om die reinigingstraf in die vagevuur te vermy.

As die vereenvouding van die boetedoening eers kerklike praktyk word, ontwikkel dit betreklik vinnig. As die persoonlike deelname aan 'n kruistog as 'n aflat van kerklike strawwe geld, dan word die moontlikheid ook geskep dat die deelname aan 'n kruistog op 'n ander manier moontlik moet wees. Dan word dit moontlik om 'n volle aflaat tc verkry deur of 'n plaasvervanger op 'n kruistog te stuur óf deur 'n geldskenking ${ }^{6}$ ). Geleidelik brei hierdie laaste moontlikheid en word die opening geskep om aflate te koop en word dic aflaathandel as 'n sacrum negotium (d.i. heilige handel) deur die roomse kerk gesanksioneer tot so 'n mate dat Sixtus IV in 1476 dit moontlik maak dat nie alleen die gelowiges aflate reëlmatig vir hulle eie kerklike boetedoening kan koop nie maar dat ook ten behoewe van die gestorwenes in die vagevuur aflate gekoop kan word. Hierdeur is die aflaathandel nie alleen gestimuleer nie mar het dit geweldig an

6) Hier word die germaans-regtelike beginsel ingevoer dat 'n strai deur geld aflosbaar is -- èn die invoering van hierdie beginsel word juis moontlik vanweë die pouse se behoefte aan geld (vgl. H. Boehmer, a.a.O., S. 143 - 144). Alexander III gee in 1166 'n gedeeltelike af'aat aan diègene wat deur middel van 'n geldskenking die destydse kruistog steun terwyl Gregorius VIII in 1187 'n volkome aflaat gee aan diegene wat 'n plaasvervanger salarieer om op 'n kruistog te gaan. Innocentius III gee in 1215 'n volkome aflaat aan diégene wat slegs 'n geldskenking terwille van die kruistog gee sonder om 'n plaasvervanger te stuur. So word die aflaat geleidelik 'n geld-maak middel. 
populariteit gewen. Hiervandaan het die aflaathandel sy hele donker, afdraande pad gegaan totdat dit duidelik was dat dit in die aflaathandel puur en simpel om die geld van die gelowige gaan en nié om sy sieleheil nie. Dan word die aflaathandel 'n finansiële saak waarmee die pouse hulleself verryk en dit is bekend dat Leo $\mathrm{X}$ die aflaatinkomste gebruik het om sy dobbelpartye mee te finansier terwyl Alexander VI die inkomste van die aflaat in 1500 ter beskikking stel van sy seun Cesare Borgia wat as een van die berugste gifmoor denaars in die geskiedenis bekend staan ${ }^{7}$ ).

So het die hele aflaathandel uitdrukking by uitstek van die verwêreldliking van die middeleeuse kerk geword - so het die werkgeregtigheid, die moralisties-geïnspireerde goeie werk van die mens, op die voorgrond getree en is die aflate op die markte van die middel. eeuse wêreld verhandel as ' $n$ genademiddel van God. ${ }^{8}$ ). Met hierdie hele aflaatpraktyk het die middeleeuse kerk nie alleen die Evangelie nie maar ook die gelowige mens se behoefte aan sekerheid verraai. Die menslike inhaligheid het die pouse van Rome verlei om die mag, invloed en aansien van die kerk te gebruik om daardeur die mense, die lidmate wat aan hulle sorg toevertrou was, op dwaalweë te verlei.

Martin Luther het reeds 'n geruime tyd vóór 1517 sy bedenkings teen die hele aflaathandel gehad. Uit ondervinding as biegvader het hy geleer dat die aflaat beskou is as 'n vrybrief vir elke moontlike sondige daad wat die mens kon begaan en om daardie rede het hy geoordeel dat die aflaat 'n verwoestende rol gespeel het ten opsigte van die vroomheid en die geloof van die middeleeuse lidmate. Luther het reeds in 1516 en daarna weer in Februarie 1517 baie skerp teen die aflaathandel gepreek en gestel dat die aflaathandel nie alleen die botesakrament aantas nie maar ook die ware gevoel van berou oor die sonde want dit leer die gelowiges om die sonde te minag en bied aan hulle 'n gevoel van gerustheid wat egter volkome vals is ${ }^{9}$ ).

Luther se verset teen die aflaathandel word egter op die spits gedryf wanneer in 1517 die aflaathandelaar, die dominikaanse monnik, Johann Tetzel, naby Wittenberg aflate begin verkoop waarvan die geld bedoel is vir die bou van die Pieterskerk in Rome ${ }^{10}$ ): Hoewel

7) H. Boehmer, a.a.O., S. 149.

8) In 1517 word 'n Solemne iudicum deur die middeleeuse kerk uitgevaardig waarin bepaal word dat dit kettery is om die heilskrag van die aflaat en die beskikkingsreg van die pous oor die skat van oortollige goeie werke van die kerk, in twyfel te trek.

๑) W. Köhler, a.a.O., S. $94 \mathrm{ff}$.

10) Johann Tetzel is ongeveer 1465 te Pirna gebore en wa's van 1501 tot 1510 al aflaatprediker. Sinds 1516 was hy deel van die hof van Aartsbiskop Albrecht van Mainz. Na Luther se aanvalle op die aflaat en op Tetzel, is Tetzel baie gou op die agtergrond gedruk sodat Tetzel in 'n dominikaanse klooster in Leipzig sy laaste lewensjare slyt. Kort voor sy dood in 1519 het Luther hom nog 'n troosbrie geskrywe vgl. Voorrede tot Band I van sy Latynse Werke, 1545; W.A , 54, 184, 12 ff. 
Keurvors Friedrich van Sakse Tetzel verbied het om in Wittenhorg sy aflate te verkoop, het Tetzel so na as moontlik aan Sakse sy aflaathandel aan die gang gesit sodat baie Wittenbergse inwoners, net oor die grense, te Jüterborg en Zerbst, aflate gaan koop het ${ }^{11}$ ). Dan kry Luther ook 'n boekie in die hande, uitgegee onder die gesag van die aartsbiskop van Mainz, waarin onder andere gestel word ${ }^{12}$ ):

„Die rooi aflaatkruis versier met die wapen van die pous, wat nou in die kerk opgerig word, het netsoveel krag as die Kruis van Jesus Christus.

Dat as Petrus dan dáár sou gewees het, sou hy geen groter genade of gesag as die aflaatprediker hê nie.

Die aflaat-genade is dié genade waardeur die mens met God versoen word.

Dit is nie nodig om berou te toon, boete te doen of te ly terwille van ' $n$ mens se sonde nie as ' $n$ mens maar 'n aflaatbrief of 'n aflaat koop".

Juis hierdie boekie spoor Luther an tot die daad en hoewel hy in uitvoerige skrywe aan die aartsbiskop van Mainz rig ${ }^{13}$ ), het hy dit terselfdertyd nodig geag om op 31 Oktober 1517, op die vooraand van 'n groot aflaatfees in Wittenberg sèlf, sy vyf-en-negentig stellings openbaar te maak.

\section{Die Vyf-en-negentig Stellings - die sentrale inhoud.}

Die vyf-en-negentig stellings ${ }^{14}$ ) self is in 'n aantal hoofstukke verdeel en daarin vat Luther alles saam wat volgens sy insig vanuit die Heilige Skrif gesê moet word teen die aflaat; die pouslike vergiffenisgesag; die twyfelagtige $\mathrm{krag}$ van die aflaat; die verhouding van die aflaat tot die goeie werke van die mens en dan eindig hy met 'n aantal skerp stellings teen die aflaatpraktyk wat ook as bedenkings teen hierdie praktyk onder die gewone lidmate geleef het.

Die sentrum van die vyf-en-negentig stellings, die kardinale punt waar alles vir Luther egter om draai, word saamgevat in stelling 62 :

„Die ware skat van die kerk is die hoogheilige Evangelie van die eer en genade van God".

Met hierdie stelling het Luther ook die sentrale moment in die reformatoriese geloof raakgevat. In sy verklaring van die vyf-en-negentig stellings, die Resolutiones disputationum de indulgentiarum virtute,

11) H. Boehmer, a.a.O., S. $155 \mathrm{ff}$.

12) Wider Hans Worst, W.A. 51, 538, 23 ff.

13) W.A., Br. 1, 110, 5 ff.

14) W.A. 1, 233 ff. 
brei Luther as volg op hierdie stelling uit :

„Wanneer die sondige gewete hierdie allermooiste boodskap (dit is die Evangelie) hoor, word dit weer lewendig, juig en jubel dit en is dan vol vertroue en vrees nóg die dood, nóg die doodstraf, nòg die hel. As iemand nog voortdurend bang is vir hierdie strawwe, dan het hy nog nooit die stem van Christus of van die Evangelie gehoor nie maar alleen die stem van Moses. Daarom word uit hierdie Evangelie die ware eer van God gebore insover dat ons geleer word dat nie deur ons werke nie maar deur die ontfermende genade van God in Christus die wet vervul is en vervul word, nie deur die werke nie maar deur die geloof, nie daardeur dat óns iets aan God aanbied nie, maar daardeur dat ons alles van Christus ontvang èn daaraan deel kry - van Hom, uit daardie oorvloed, sal ons almal alles ontvang en uit daardie oorvloed, sal ons almal alles ontvang en in alles deelkry".

Dit gaan dus vir Luther om die Evangelie, die eer en heerlikheid van God en hierdie Evangelie beklemtoon nié die egoïstiese begeertes van die méns nie, maar beklemtoon die noodsaaklikheid dat die mens, in antwoord op die hoor van hierdie Evangelie, die wil van God uit dankbaarheid sal doen en die werke van barmhartigheid aan sy naaste, uit dankbaarheid, sal bewys ${ }^{15}$ ).

Met hierdie vyf-en-negentig stellings en veral met hierdie sentrale stelling 62 het Luther teenoor die verwêreldlikte kerk en teenoor 'n godsdiens en 'n vroomheid wat die mens met sy werke en sy moontlikhede om die ewige heil te verdien, in die middelpunt plaas, 'n kragtige oproep gemaak om die heerskappy van Jesus Christus weer in die kerk en in die lewe van die gelowige te aanvaar en te bely. Die belang van hierdie oproep lê daarin dat hier vir die eerste maal in die middeleeuse kerk, openlik en duidelik, grondliggende en Skriftuurlike kritiek teen die bestaande godsdiens en vroomheid, soos dit verword het, uitgespreek word.

Met 'n duidelike en vir hom so kenmerkende eenvoud, vee Luther die mensgemaakte versperrings waarmee Christus op die agtergrond van die kerklike lewe gedruk is, weer weg en stel in alle eenvoud en met groot helderheid : Jesus Christus is alleen en volkome en in elke opsig die Koning en Heer van die Kerk. Christus se oproep tot boete omvat die hele lewe van die mens, tot die laaste oomblik, en elkeen wat deur die geloof Jesus Christus liefhet en Hom gehoorsaam is, kan en sal nie vlug vir boetedoening en straf nie maar betoon juis sy gehoorsaamheid aan Jesus Christus deur boete te doen en die

15) Stelings 41 - 51 . 
straf te dra vir die eie sondigheid egter in die wete dat Jesus Christus, die Here, die Verlosser van die sonde is.

Daarom beklemtoon Luther dat Jesus Christus alléén mag en gesag het oor die oorledenes - die sleutel van die doderyk en die hel is in die hande van Jesus Christus. Die mag van die pous strek nie verder as die grense van die gewone menselewe nie, die pous se moontlikheid om sonde te vergewe gaan nie verder as hierdie ondermaanse bestaan nie. Alleen Jesus Christus het die ewige heil van die mens in sy hande en alleen $\mathrm{Hy}$ kan, vanweë sy Kruis en opstanding, die volledige vergewing van die sonde gee. In Jesus Christus, deur die geloof in Hom, die Gekruisigde, is daar vir die gelowige sekerheid van die heil - 'n sekerheid wat nooit deur 'n aflaat of 'n menslike dekreet gegee kan word nie. En die gelowige christenmens het deur die geloof deel aan al die geestelike en ewige erfenis van Jesus Christus - méér is nie nodig nie. Nòg goeie werke, nòg 'n aflaat, nòg watter menslike versinsel kan hier die geloof vervang nie.

Daarby kom dan nog hierdie verdere oorweging naamlik dat Jesus Christus die Heer is van die kerk, 'n kerk wat net één taak op aarde het naamlik om die Evangelie van Jesus Christus te verkondig - die goeie boodskap van die Kruis en die Opstanding; die vreugdevolle boodskap van die vergewing van die sondes; die bevry' dende boodskap dat die mens géén enkele bydrae hoef te maak of kan mak tot sy verlossing nie maar dat die verlossing, om Christus ontwil, aan die gelowige gegee word. Géén ander woord, geen aflaatprediking, geen mensgemaakte verlossingsleer mag in die plek gestel word van hierdie Evangelie wat die kerk moet verkondig nie. Want vir Luther is dit duidelik dat ' $n$ mensekind op aarde nog sonder die sakramente, sonder die aflatprediking, sonder baie ander dinge kan lewe maar nooit sonder die Woord van God, die Evangelie nie ${ }^{16}$ ). As daar dus ' $n$ skat in die kerk is dan is dit die Evangelie wat die aangevog. tenes troos, die gebondenes vrymak, die beangstes en twyfelaars verlos van hulle vrees vir die dood en die ewige verdoemenis ${ }^{17}$ ).

Die kerk is nie 'n soort bank wat aflate kan verkoop nie, die kerk is ook nie die draagster van 'n soort verhewe moraalleer nie, maar die kerk is dié plek waar die Evangelie verkondig word, waar valse sekerhede afgebreek en die sekerheid van die heil, deur die geloof in Jesus Christus, uitgedra word. Die kerk het die een, allesoorheersende taak om die hoogheilige Evangelie van die eer en die genade van God uit te dra aan 'n sondige, verloregaande mensdom. Al die ander, menslike oorwegings, gedagtes en doenighede in die kerk

16) Vgl. Stelling 55 .

17) Stellings $56-68$. 
moet ondergeskik gemaak word aan hierdie dienswerk wat die kerk van Godsweë opgedra is ${ }^{18}$ ).

Met hierdie Bybelse boodskap, waarmee Luther die verhoudinge weer Skriftuurlik aangedui het, het Luther terselfdertyd die middeleeuse, roomse kerk waar die mens en die menslike instellings in die plek van God, sy Woord en sy genadige ontferming oor die mens gaan staan het, in sy fondamente aangetas. Hoewel Luther dit in 1517 nie ten volle besef het nie, was dit tog so en was heel Luther se latere werk èn die van die ander reformatore 'n voortsetting en 'n omvattende uitbreiding van die beginselstandpunt wat Luther op 31 Oktober 1517 ingeneem het. Soos Johannes Calvyn dit later so treffend gestel het ${ }^{19}$ ):

„Want in die begin, toe Luther en sy geesgenote die pous tereg. gewys het ten opsigte van al die growwe misstande, het hulle skaars 'n duidelike opvatting van die ware Christendom gehad. Maar toe die pous teen hulle te velde getrek het en hulle uit die sinagoge van Rome verban is, het Christus sy hand na hulle uitgesteek en het $\mathrm{Hy}$ ten volle aan hulle bekend geword".

Wat Luther op 31 Oktober 1517 in sy vyf-en-negentig stellings formuleer, is die beginpunt van die kerkhervorming, 'n beweging wat onder die seënende hand van God so 'n enorme invloed gehad het èn het dat ons tot vandag toe die impuls van daardie beweging voel. Dit is ' $n$ beweging wat in 1517, nog heeltemaal onbewus, die pous en die hele roomse hiërargie uitgedaag het en wat die begin was van 'n beweging wat 'n halwe wêreld van die dwinglandy van die pous bevry het. Sentraal in die cerst oproep tot die hervorming van die kerk staan hierdie stelling van Luther:

„Die ware skat van die kerk is die hoogheilige Evangelie van die eer en genade van God".

\section{Die belang van die Vyf-en-negentig Stellings vandag.}

Die vraag wat nou, baie oorsigtelik, beantwoord moet word, is die vraag: Wat het die vyf-en-negentig stellings van Martin Luther vandag nog aan ons te sê? Ons is mos erfgename van die kerk. hervorming van die sestiende eeu en assodanig is die vyf-en-negentig stellings deel van die hele ryke erfenis wat ons uit die sestiende eeu ontvang het. Natuurlik is dit ook so dat ons meer uit die tradisie en leer van die latere hervormer, Johannes Calvyn, leef maar aangesien

18) In sy verklaring van Stelling 55 sê Luther: Dit is nog beter om die sakrament te verwaarloos as om die Evangelie nie te verkondig nie.

19) Aangehaal by D. Nauta, Calvin and Luther, artikel in Opera Minora, Kampen 1961, blz. 17. 
daar in die hoofsake van die leer, uitgenome die leer van die Awendmaalssakrament weinig of geen verskil is tussen hierdie twee uitnemende diensknegte van die Here nie, is ook die werk van Luther deel van ons erfenis uit die sestiende eeu ${ }^{20}$ ).

Tog weet ons ook dat die hervorming van die kerk, die gehoorsaamheid aan die Woord van God, nooit 'n afgeslote saak is nie. Die feit bly staan dat ons as mense in die kerk tegelyk regverdige en sondaaar bly en daarom voortdurend ons moet bekeer tot die waar. heid van die Evangelie, voortdurend ons gehoorsaamheid en dank. haarheid moet opskerp. Daarom het ons dit voortdurend nodig om daaraan herinner te word dat die ware skat van die kerk die hoogheilige Evangelie van die eer en genade van God is. Immers die versoeking lê voortdurend langs ons dat ons ook, in die kerk, ons menslike vermoëns en doenighede hoër sal ag as Gods grote dade; dat ons nic durf om uit die geloof alleen te lewe nie maar liewer soek na die sekerheid van 'n mensgemaakte moraalleer wat ons dan hoër ag as die eer en genade van God. Ook by ons is die moontlikheid voortdurend aanwesig dat ons in ons godsdiens en in ons vroomheid eerder sal laat lei deur ons menslike egoïsme as deur ons vertroue op en geloof in Jesus Christus, die gekruisigde en opgestane Heer. Dáárom, vir hierdie en nog meer redes, is dit nodig dat ons voortdurend herinner sal word an die sentrale momente van die Evangelie soos dit so uitnemend saamgevat is deur Martin Luther en Johannes Calvyn.

Tog is daar ' $n$ verdere rede waarom juis ons van vandag dit nodig het om weer met groot sorg, aandag en toewyding te luister na die boodskap van die kerkhervorming van die sestiende eeu. Dit egter nie alleen omdat die roomse kerk van ons dae trag om met 'n duideliker stem te spreek nie want die prinsipiële protes en aanklag van die kerkhervorming teen die roomse kerk staan tot vandag toe. Hoewel die roomse kerk, sinds die sestiende eeu, op verskillende punte verander het, het ons nog steeds geen grond om vraag en antwoord 80 uit die Heidelbergse Kategismus te verwyder nie. Die indruk bly tot vandag toe dat die roomse kerk nog nooit werklik geluister het na die stem van die reformatoriese protestantisme nie en daarom kan ons nie anders as om ons prinsipiële Nee! teenoor Rome te handhaaf nie.

Die groot rede waarom ons vandag na die sentrale boodskap van

20) Vgl. D. Nauta, a.20., blz. 27: It is true that in many respects there is no difference between Calvin's ideas and that of Luther, but it is not true that he only furnished a duplicate of Luther. Calvin had Luther as a starting point, and without difficulty he remained loyal to his great predecessor. 
die kerkhervorming moet luister, lê eerder daarin dat in ons tyd en ook in ons midde, ' $n$ godsdienstige stroming te voorskyn gekom het wat, hoewel dit aanspraak maak op Bybelse gesag, in wese 'n verloëning is van die Evangelie van Jesus Christus. Ek dui hier op die social gospel wat in ons tyd daarin geslaag het om so in te dring in die protestantisme dat die social gospel en nié die Evangelie nie, dié boodskap is wat deur die wêreld as die essensieel-christelike boodskap gewaardeer word.

Hierdie social gospel, as ek dit kortliks mag omskrywe, is die intense belangstelling in die sosiale en politieke lewe en aspirasies van die mens, die uitdra van die boodskap van die regte en die vry. hede wat die mens glo moet besit. Hier gaan dit om die mens en sy verlangens en begeertes vir hiérdie lewe, dit is die boodskap dat die mens hier op aarde die nuwe hemel en die nuwe aarde sélf moet bou en nié daarvoor op God moet wag nie. Dit is hierdie social gospel wat 'n beginselverklaring van die Wêreldraad van Kerke ontlok het naamlik :

,We are concerned with social justice, that is to say with the development of social conditions in which human dignity and freedom can find their expression as befits the nature and destiny of man as a child of God".

Dit is hierdie social gospel wat sy regverdiging probeer soek in Jesus Christus se samevatting van die tweede tafel van die Wet (Mt. 21 : 39 -40) nl. "Jy moet jou naaste liefhê soos jouself" maar dan losgemaak van die samevatting van die eerste tafel van die Wet. Hierdie „naasteliefde" word dan uitgelê met begrippe soos : the brotherhood of man, social justice, togetherness, human rigths en dergelike meer wat hulle oorsprong eerder vind in die buite-christelike, links-sosialistiese denke van ons tyd. Vanuit hierdie uitgangspunt word 'n godsdienstige denkpatroon geskep wat nie alleen volkome afwyk van die Bybels-reformatoriese teologie nie maar wat onder andere rasseintegrasie as 'n voorwaarde vir die christelike geloof stel en wat skynbaar ' $n$ behae daarin skep om die voortbestaan van die blanke christendom in suidelike Afrika te ondermyn en te ondergrawe. Dit is hierdie social gospel wat hom daarvoor beywer om ook in suidelike Afrika 'n multi-racial, international community (of dit nou christelik is of nie!) te vestig al beteken dit dat om dit te bereik 'n verbond met die nie-blanke heidendom gemaak moet word om so die blanke christendom in suidelike Afrika onder te ploeg ${ }^{21}$ ).

Die social gospel het sodanig ingesluip in die protestantisme van

21) Vgl. The Future of Sonth Africa. A Study by British Christians, London 1965. 
ons tyd dat nog in Junie 1964 deur 'n samekoms van kerklike amps' draers in die teenswoordige Zambië besluit is dat spiritual resistance, constructive political opposition, extra-constitutional activity en violence ${ }^{22}$ ) dié middele is wat christene mag gebruik to improve race relations in suidelike Afrika! Hoewel bygesê kan word dat sommige deelnemers aan die beraad hulle gedisassosieer het van die besluite en om industrial destruction en internal violence as uitnemend christelike optrede in suidelike Afrika aan te beveel, het die Sentrale Komitee van die Wêreldraad van Kerke in Januarie 1965 tog kans gesien om hierdie besluite so oor te neem ${ }^{23}$ ).

Hierdie godsdienstige denkpatroon wat die Evangelie van Jesus Christus as moraalleer misverstaan en juis op daardie punt geinfiltreer is deur die demoniese, rasionele moralisme vertoon verskil. lende trekke wat ooreenstem met die godsdienstige situasie van die tyd van Luther. Ook hier, by die social gospel, is die aandag afgetrek van die Here God en wat $\mathrm{Hy}$ doen en gekonsentreer op die mens. Ook hier gaan dit nié om die verlossing uit die sonde en van die dood wat Jesus Christus aan die mens as 'n genadegawe, as 'n vrug van sy Kruis en Opstanding bied nie, maar gaan dit om die self-verlossing wat die mens moet bereik deur hoofsaaklik op sosiale en politieke vlak sogenaamde, "goeie werke" te doen wat dikwels beteken die benadeling van die bestaande kerklike christendom ten behoewe van van die heidendom

Juis omdat deur die social gospel al die aandag gekonsentreer word op die mens, omdat dit 'n denkrigting is wat hoofsaaklik gekonsentreer is op die mens en sy doenighede in hierdie en ten opsigte van hierdie lewe, omdat dit vir die mens moontlik geag word om nou reeds die nuwe hemel en die nuwe aarde te verwerklik, dáárom kan hierdie social gospel 'n soort van kerklike eenheid, 'n soort togetherness propageer wat rustig alle konfessionele verskille verbygaan en wat ewe gelate die Waarheidsvraag links laat lê.

Hierdie social gospel wat vandag in die protestantisme buite ons grense en veral in Amerika so populêr is, wat hier in ons land ook met ' $n$ wisselende mate van sukses uitgedra word, is 'n wesenlike bedreiging vir die Bybels-reformatoriese teologie soos ons dit opgeteken vind in die Belydenisskrifte van ons Afrikaanse kerke en dit kan miskien ook vertolk word as 'n poging om ons te vervreem van ons

22) Wat in Afrika onder violence verstaan moet word, word baie duidelik uit die werk van B. Teixeira, The Fabric of Terror, Kaapstad 1965.

23) Vgl. In hierdie verband die berigte in die Rand Daily Mail van 3.6.196-1 asook die Hoofartikel van 4.6.1964 in verband met die vergadering wat by die Mindolo Ecumenical Centre in Kitwe gehou is onder beskerming van die Wêreldraad van Kerke en die S.A. Institute for Race Relations. 
hele ryke erfenis uit die sestiende eeuse kerkhervorming, dit kan ook verstaan word as 'n poging om ons uiteindelik te vervreem van die Evangelie van Jesus Christus.

Immers in die Evangelie gaan dit om Gods grote dade, om die verlossing wat $\mathrm{Hy}$ ons in en deur Jesus Christus geskenk het. Soos Martin Luther dit êrens gestel het:

„Alleen Christus het die Wet vervul. Die ergste sonde is dan ook as ons nou weer gaan probeer om met eie krag die Wet te vervul. As ons dit doen, beledig ons Jesus Christus. Ons kan die Wet alleen vervul deur Sy vervulling, dit is Sy gereg. tigheid, in die geloof te aanvaar. Hy wat sê dat die Wet nog vervul moet word, bly in die sonde; hy herstel die mag van die sonde weer terwyl dit juis deur Jesus Christus vernietig is.

Beteken dit dat ons geen goeie werke hoef te doen nie? Allermins. Maar ons mag nie goeie werke doen om daarmee iets te probeer bereik nie. Ons doen goeie werke alleen om in vryheid en gehoorsaamheid, Christus, onse Here, te dien. Geregtigheid is dus geloof in Jesus Christus. 'n Mens lewe nie omdat hy regverdig is nie, hy is regverdig omdat hy in Jesus Christus glo".

Dit gaan in die Bybels-reformatoriese teologie om God en nié primêr om die mens nie, Gods dade is belangriker en die mens se daad-in. antwoord, sy geloof en sy gehoorsaamheid, ook aan die tweede, groot gebod, word gedoen uit dankbaarheid en nié met die bedoeling om iets daarmee te verdien of te bereik nie.

Daarom het die kerk ook geen ander taak as om die Evangelie, die goeie boodskap van Gods ontferming en genade uit te dra nie en mag die kerk nooit word tot 'n politieke drukgroep of 'n middel om sosiale kruistogte te bevorder nie. Immers die boek Handelinge van die Apostels is niks anders as die uitleg dat die liefde tot God, die liefde tot die naaste tot gevolg het dit wil sê dat aan die medemens die Evangelie van Jesus Christus, die goeie boodskap van die verlossing van die sonde en die bevryding uit die mag van die dood, gebring word nie. Laat my toe om Luther weer aan te haal :

„Die Almagtige God het ons in die Nuwe Testament beveel om niks te verkondig behalwe sy geliefde Seun Jesus Christus nie. Dáártoe het God alle ander boeke en elke ander leer vir ons gesluit sodat ons daar geen aandag aan sal gee nie, maar ons alleen sal verdiep in die èèn boek wat ons omtrent Jesus Christus onderrig gee. Teenoor al die uitsprake van die kerkvaders, teen. oor al die sprake van mense, engele en duiwels staan die Heilige 
Skrif. Hierby staan ek, hier hou ek stand, hier daag ek uit en sê: Gods Woord is vir my meer werd as al die ander! Goddelike majesteit staan aan my kant ..... en ek is oortuig dat die ware kerk met my vashou aan die Woord van God, Jesus Christus".

Ons lewe vandag, as erfgename van die kerkhervorming, in 'n tyd waar nie net die suigkrag van die wêreld nie maar ook 'n groot deel van die protestantse kerk dit vir ons as lidmate en ampsdraers van die Afrikaanse kerke moeilik maak. Daar word 'n duidelike en in kragtige poging aangewend om ons te vervreem van ons erfenis -in die naam van vooruitgang, verligting, van redelikheid en mede. menslikheid word ons gevra om ons reformatoriese geloof te verloën. Miskien het die tyd juis nou aangebreek dat ons baie deeglik moet besin oor wat ons erfenis is en wat dit vir ons beteken. Maar as ons dan nadink, laat ons dan begin by 31 Oktober 1517 en laat ons weer opnuut besef dat die enigste ware skat van die kerk die hoogheilige Evangelie van die heerlikheid en genade van God is. Dit moet ons besef en glo en uitleef. So eenvoudig, so alles-omvattend is ons opdrag vir hierdie tyd.

Laat my toe om ter afsluiting, dit te verklaar met hierdie woord van Martin Luther wie se baanbrekende werk ons vandag gedenk:

„,Hier - dit is deur die Evangelie - . . . word ons geleer dat ons deur Christus, Gods Seun, verlos is van die dood, waarin ons deur Adam se sonde geval het sodat ons ewiglik verderf moes word. By die geloof in Jesus Christus kom dit egter dáárop aan dat ons met goeie moed ons onder die verlostes sal reken, sonder om daaraan te twyfel. Vir hierdie genade moet ons God voortdurend van harte dank en oor ons verlossing deur die Kruis van Jesus Christus bly wees.

„Verder moet ons bitterlik skaam oor ons ongeloof en twyfel aan Gods genade en hierdie sonde moet ons voor God bely. En wat sal ons nie hier alles opnoem nie! Die afgodediens wat ons beoefen naas die diens van God, al ons eiesinnige pogings om deur ons goeie werke die saligheid te verdien, al ons dade waarmee ons Gods verlossing deur die Kruis van Jesus Christus teengestaan het. Bid daarom dat God julle by die ware en suiwere geloof in Jesus Christus julle Heer sal bewaar - nou, in die toekoms, en tot die einde".

A. D. PONT. 